\title{
A juventude dos imperadores romanos Caracala e Geta: questões políticas, familiares e numismáticas
}

\author{
The youth of the Roman emperors Caracalla and Geta: some \\ reflexions on politics, family and numismatic
}

\begin{abstract}
Ana Teresa Marques Gonçalves*
Resumo: Nos documentos textuais latinos, produzidos nos séculos III e IV, temos poucas informações sobre a juventude dos filhos e herdeiros do Imperador Romano Lúcio Septímio Severo com Júlia Domna, Caracala e Geta. Eles só passam a interessar aos autores quando ascendem ao comando imperial em 211, após a morte do pai, na Bretanha, quando já têm respectivamente 23 e 22 anos de vida. Contudo, no afã de divulgar a união familiar e a continuidade da gens Septímia no poder, foram cunhadas várias moedas com a imagem dos herdeiros ainda muito jovens e imberbes. Neste artigo, buscamos analisar o uso político da coesão familiar como matriz da governabilidade severiana, a partir da emissão de mensagens via suportes textuais e numismáticos, nos quais identificamos representações dos ainda jovens Caracala e Geta.
\end{abstract}

\begin{abstract}
In the Latin textual documents, produced in the 3rd and 4th centuries $A D$, we have little information about the youth of the sons and heirs of the Roman Emperor Lucius Septimius Severus with Julia Domna, Caracalla and Geta. They only became of interest to the authors when they ascended the imperial command in A.D. 211, after the death of their father, in Brittany, when they were respectively 23 and 22 years old. However, in order to promote family unity and the continuity of the Septimia gens in power, several coins were minted with the image of the heirs who were still very young and beardless. In this article, we seek to analyze the political use of family cohesion as a matrix of Severian governance, from the emission of messages via textual and numismatic supports, in which we identify representations of the still young Caracalla and Geta.
\end{abstract}

\author{
Palavras-chave: \\ Caracala. \\ Geta. \\ Família. \\ Juventude. \\ Moedas.
}

\footnotetext{
* Professora Titular de História Antiga na Universidade Federal de Goiás. Doutora em História pela Universidade de São Paulo. Bolsista Produtividade II do CNPq. Coordenadora do Leir-GO.
} 
$\mathrm{N}$ os documentos textuais pagãos, produzidos por historiadores e/ou autores de epítomes, nos séculos III e IV, encontramos pouquíssimas informações a respeito da juventude dos filhos e herdeiros do imperador romano Lúcio Septímio Severo com sua segunda esposa, a síria de Emesa, Júlia Domna. Deste enlace matrimonial, nasceram dois meninos. Em 4 de abril de 188, na cidade de Lugdunum, na Gália, atual Lyon, na França, nasceu Lúcio Septímio Bassiano, nome dado em homenagem a Júlio Bassiano (Epitome de Caesaribus, XXI, 1; XXIII, 2), pai de Júlia Domna e famoso sacerdote do templo dedicado ao deus Elagabal, em Emesa. Foi renomeado como Marco Aurélio Antonino, quando se tornou César, em 195, a pedido de Septímio, como forma de vincular a família Septímia à família dos Antoninos, após o pai se proclamar filho do imperador Marco Aurélio. Como afirma Dion Cássio (Historia Romana, LXXVI, 8, 1-2):

Ele (Severo) nos causou especial espanto ao constantemente se intitular filho de Marco e irmão de Cômodo e concedendo honras divinas a este último [...]. Enquanto lia para o Senado um discurso, ele elogiou a crueldade de Sula, Mário e Augusto como um curso seguro e reprovou a suavidade de Pompeu e César como responsável pela ruína destes homens. Depois ele introduziu um tipo de defesa de Cômodo e censurou o Senado por tê-lo desonrado injustamente; em vista deste fato, a maioria dos membros passou a temer por sua vida.

A lembrança das desmedidas de Cômodo assustaram o Senado, mas era impossível se vincular à imagem de Marco Aurélio sem procurar reabilitar a de Cômodo, seu filho e herdeiro. Contudo, senadores fizeram pilhérias a respeito da inovação proposta por Severo, ao adotar um pai ao invés de ser adotado por ele. $\mathrm{E}$ é mais uma vez Dion Cássio (Hist. Rom., LXXVII, 9, 4) quem nos conta:

Quando o imperador se registrou na família de Marcos, Auspex (o importante senador Aurélio Polênio Auspex) falou: "Eu o comprimento, César, por ter achado um pai!", comentando que até esse momento ele não tinha tido pai devido a seu obscuro nascimento.

Parece, desta forma, que a vinculação mais estreita à memória de Marco Aurélio teria agradado a vários senadores, mas a reabilitação de Cômodo teria provocado o efeito inverso. Entretanto, parece-nos já indicar a intenção severiana de elevar seus próprios filhos a herdeiros do comando imperial. Lembremos que, em 195, Severo estava finalizando as guerras civis travadas contra Pescênio Nigro e Clódio Albino, das quais saiu vencedor. Por isso, em 28 de janeiro de 198, após importantes vitórias bélicas contra os partos, Bassiano foi elevado a Augusto. Em 202, este casou-se com Públia Fúlvia Plautila, filha do prefeito do pretório e amicus africano de Severo, Caio Fúlvio Plautiano (Herodiano, Historiae, III, $10,6)$, de quem se divorciou em 205. Entretanto, passou à história conhecido por seu 
apelido, Caracala, nome dado a uma longa túnica, que descia até os calcanhares e que ele usava com frequência, talvez buscando enfatizar sua origem gaulesa, como nos informa Sexto Aurélio Victor (Caesares, XXI, 1). Foi assassinado em 217, a mando do prefeito do pretório, Opélio Macrino, aos 29 anos.

Já o irmão mais novo, Públio Septímio Geta, nasceu em Mediolanum, atual Milão, na Itália, em 7 de março de 189, tendo como nome uma homenagem ao pai de Severo (GONÇALVES, 2019, p. 165). Tornou-se César em 198, quando seu irmão mais velho tornou-se Augusto. Foi cônsul em 205 e 208 Em 209, foi aclamado Augusto, passando a integrar a linha sucessória junto com o irmão. Acabou assassinado a mando de Caracala em 26 de dezembro de 211 (Historiae Augustae, Vida de Geta, III, 1), logo após a morte de Severo em Eburacum, atual York, na Inglaterra, devido a complicações causadas pela gota, aos 65 anos. Após a morte de Geta aos 22 anos, literalmente no colo da mãe, como nos conta Dion Cássio (Hist. Rom., LXXVIII, 2, 1), Caracala pediu ao Senado a damnatio memoriae do irmão, o que lhe foi concedido (VARNER, 2004, p. 169). Por isso, temos poucas imagens de Geta. Porém, como muitas moedas eram entesouradas e seu valor era real e não nominal como hoje em dia, sobraram-nos várias efígies de ambos os irmãos.

Seguindo os pressupostos de Augusto Fraschetti (1996), no capítulo sobre o mundo romano, no livro História dos Jovens, podemos afirmar que Caracala e Geta só passaram pela infância e pela adolescência, ou seja, nunca chegaram à idade adulta, segundo os cânones cronológicos latinos. Para Fraschetti (1996, p. 70), a partir de uma releitura das obras de Varrão, continuava-se puer até os 15 anos, passava-se pela adulescentia dos 15 aos 25 ou 30 anos e pela iuventa dos 25/30 anos até os 40/45 anos. Vê-se, desta forma, como as definições dos grupos etários tinham muito mais a ver com o pertencimento às instituições militares e políticas do que com os ciclos biológicos das vidas humanas. Lembremos que a passagem dos iuniores para seniores, tanto no exército quanto no Senado, dava-se ao completar 45 anos (TALBERT, 1984, p. 36). Talvez possamos explicar tal datação, que aos olhos contemporâneos parece tão tardia, pela extensão da patria potestas pelo pater familias, ou seja, enquanto o filho não atingisse a idade adulta, o pai continuava tendo sobre ele o poder de vida e morte (FRASCHETTI, 1996, p. 71). Assim, o que podemos determinar como adolescência ou juventude deve ser caracterizada como o início da carreira das honras, quando o rapaz poderia passar a ocupar cargos públicos e magistraturas, candidatando-se e/ou sendo eleito, demonstrando possuir conhecimentos e aptidões para o exercício da função pública, tendo menos a ver com a idade biológica em si do que com o desenvolvimento de capacidades físicas e cognitivas, que o habilitavam para auxiliar na condução dos negócios comunitários. 
Philippe Ariès (1981), no famoso livro História Social da Infância e da Família, só identifica uma determinação de uma infância aproximada com a que temos hoje a partir do século XIII e, mesmo assim, ela teria mais a ver com a necessidade de conservação dos bens familiares, a aprendizagem da prática de um ofício e a ajuda cotidiana na manutenção e na proteção da família do que com marcos cronológicos exatos (ARIÈS, 1981, p. 13). Mais interessado na relação produzida entre a escola e a família no mundo moderno, a partir do estudo de ampla iconografia, este autor enfatiza que qualquer trabalho sobre infância e juventude não pode escapar do estudo das instâncias e dos relacionamentos familiares. No mundo romano, cremos não ser diferente, pois, como vimos, até a escolha dos nomes dos filhos vinha da necessidade de se vincular a determinada gens e de se homenagear certos expoentes familiares. O núcleo familiar, na Antiguidade latina, era extenso e não nuclear, como atualmente, e o culto aos Lares, Manes, Genius e antepassados em geral era crucial para o ordenamento familiar (COULANGES, 1982, p. 98).

A passagem dos ciclos deveria ser motivo de ritos privados e públicos, para que a comunidade soubesse com quantos jovens poderia contar para cuidar dos negócios ordinários e das campanhas militares. Em razão disso, realizava-se a cerimônia de mudança da roupa ostentada pelo rapaz, quando este chegava aos 15 ou 16 anos, e passava a ostentar a primeira barba. Tratava-se da troca da toga praetexta (franjada de púrpura, com enfeites de burla) para a toga viril (branca e sem muitos enfeites, além da fíbula, o alfinete que auxiliava, às vezes, a disposição do tecido). Sabemos que Caracala tomou a toga viril em 201, na cidade de Antioquia. Já Geta passou pela cerimônia em Roma, em 202 (BIRLEY, 1999, p. 139).

O ritual iniciava-se na domus, onde, na noite precedente, o jovem, como sinal de bom augúrio (omnis causa), vestia uma túnica recta para dormir. Na manhã seguinte, o rapaz abandonava os emblemas da infância (insignia pueritiae), isto é, a bulla, ornamento que levava no pescoço com fins protetores, visto que era dedicado aos Lares, divindades que protegiam o território da casa. Em seguida, abandonava a toga praetexta e vestia a toga viril. Então, os familiares, clientes e amigos acompanhavam o jovem até o fórum e o Capitólio, para que fosse visto pela comunidade e realizasse ritos religiosos (FRASCHETTI, 1996, p. 73). Este verdadeiro cortejo demonstrava a riqueza e o poder da família, rivalizando, por vezes, com outras procissões importantes, como os triunfos e os funerais. Acredita-se que no Capitólio, onde estava o templo dedicado à tríade capitolina: Júpiter, Juno e Minerva, havia também uma estátua de culto a luventas, a Juventude, aos pés da qual normalmente o jovem depositava cachos de seus cabelos cortados na véspera. Interessante esta questão capilar, pois o aparecimento de pelos no rosto deveria 
ser seguido pela subtração dos cachos dos cabelos. Penteados com madeixas longas eram vistos como coisa de meninos ou mulheres.

Paul Veyne (1990), no seu capítulo referente aos romanos, na História da Vida Privada, sustenta que não há "menores no mundo antigo, mas sim impúberes". Um filho de senador, por exemplo, aos 16 anos tornava-se equestre; aos 17, poderia ocupar o cargo de edil, no qual cuidava da defesa da cidade; daí poderia ascender no cursus honorum até ocupar o consulado, como Geta. Aprendia suas funções ao exercitá-las com o auxílio de seus subordinados. Na infância, deveria ter aprendido as letras e os números e, na puberdade, poderia integrar os collegia iuvenum, ou seja, as associações de jovens, nas quais podia praticar esportes, caçar, frequentar as termas e os estádios (VEYNE, 1990, p. 36-37).

Em comparação com os jovens gregos, como descritos por Alain Schnapp (1996), no primeiro capítulo do livro História dos Jovens, podemos perceber como sua apresentação visual era distinta dos romanos. Ostentar cabelos longos entre os helenos era sinal de juventude, ao se reiteradamente referir-se aos velhos como os carecas, como o conhecido caso do ancião Nestor, na llíada. No início, o vocabulário indicava apenas a diferenciação entre os couroi e os gerontes, ou seja, os jovens guerreiros e os que, após os serviços militares, poderiam se dedicar totalmente à condução das questões públicas (SCHNAPP, 1996, p. 21). Com o desenvolvimento das poleis, o vocabulário se adequou às novas necessidades políades e aos costumes da efebia e da paideia, surgindo os termos paidí (criança), paidiké elikía (infância), néos (jovem) e neoi (juventude). São estes termos que aparecem nas obras produzidas por Dion Cássio e Herodiano, em grego koiné, no século III, quando se referem aos adelphoi (irmãos) Geta e Caracala, pois eles foram obrigados a traduzirem os vocábulos latinos para a língua grega ao se referirem aos Severos.

Esta diferenciação entre práticas da juventude grega e romana foi sendo elaborada para que os latinos se adequassem aos mores maiorum, isto é, aos costumes dos ancestrais, como eram idealizados pelos autores romanos. Esta necessária diferença aparece realçada na obra Vidas (Prefácio, 4-6), de Cornélio Nepote:

Com efeito, não supus desonra alguma para Címon, cidadão ateniense tão ilustre, o fato de haver tomado por esposa sua própria irmã, nascida do mesmo pai, pois seus concidadãos acreditavam que se tratava de uma instituição pública. Sem dúvida, para nós, isto se considera abominável. Assim, também em Creta é motivo de honra entre os adolescentes ter tido vários amantes. [...] Quase em toda Grécia foi motivo de grande honra haver-se proclamado vencedor em uma Olimpíada e do mesmo modo para ninguém foi motivo de vergonha haver sido ator de teatro ou ter se exibido publicamente como espetáculo frente à plebe. Entretanto, entre nós, tudo isso se considera infame, humilhante e muito longe do conceito de honra. Ao contrário, outras muitas coisas que, de acordo com 
nosso juízo e segundo nossos costumes, são dignas, entre eles se reputam como vergonhosas. Que romano sente vergonha de levar sua esposa a um banquete?

Esta passagem riquíssima demonstra como os romanos perceberam que se portavam socialmente a partir de regras diferentes das assumidas pelos gregos, tanto que Cornélio Nepote se sente impelido a avisar seus leitores/ouvintes de que dissertaria sobre práticas de generais gregos diversas das efetivadas pelos romanos, mas que estas não diminuíam em nada sua honra, pois eles as executavam tomando, como parâmetros, regras sociais impostas por outra cultura.

Na comparação dos capítulos "Virilidades Gregas", elaborado por Maurice Sartre (2013), e "Virilidades Romanas: Vir, Virilitas, Virtus", produzido por Jean-Paul Thuillier (2013), integrantes do compêndio História da Virilidade, notamos como dos jovens rapazes gregos e romanos se esperavam ações diferenciadas. O termo grego andreia designava a natureza masculina, a definição de um sexo varonil, enquanto o vocábulo anthropos definia o homem como espécie. Algo parecido pode-se entrever entre as noções latinas de uir e de homo. Contudo, em ambas as culturas a masculinidade se constrói a partir de práticas culturalmente aceitas e comunitariamente compartilhadas (SKINNER, 2006, p. 218). Deste modo, no caso romano, chegava-se à idade de homem quando a primeira barba aparecia nas bochechas. Antes disso, o menino podia ser confundido com uma mulher e por isso o relacionamento com homens barbados, portanto já formados, podia ser socialmente aceito entre os gregos na agogé espartana, com a definição dos rituais impostos pela krypteia, e na paideia ateniense (SARTRE, 2013, p. 20). Porém, entre os romanos, a noção de cives, cidadão, se impunha. O cidadão em formação na juventude ou já formado sempre deveria ter papel ativo, seja no campo político, seja no campo militar, seja no campo sexual. A posição passiva aproximava o homem do gênero feminino, que era visto como mais frágil e mais débil. O sistema piloso era importante deste ponto de vista, visto que identificava pela observação o pertencimento a uma condição viril (THUILLIER, 2013, p. 76-77). Da mulher romana se esperava a pureza e a castidade; do homem, a virilidade, a disciplina, a coragem e a honra.

John Lendon (1997, p. 1-2) demonstra, no livro Empire of honour, como a noção de honor foi paulatinamente sendo concebida pelos romanos, como forma de garantir influência social e política para os cidadãos, tornando-se um sistema moral que misturava pensamento e emoção, responsabilidades e habilidades. E honra se conquistava e se lutava para manter, pois dela poderiam advir autoridade e poder (CASINOS MORA, 2000, p. 144). E era pessoal e intransferível. Podia ser alocada e perdida. Auxiliava na condução da família, mas não apenas a partir dela era construída. Deveria ser demonstrada tanto 
em espaços públicos quanto privados e poderia ser divulgada por vários suportes numismáticos e epigráficos, gerando a fama e a existimatio, partes fundamentais do capital político de um cidadão.

Para os autores Michel Cazenave e Roland Auguet (1995), no livro Os imperadores loucos, Caracala teve sua má imagem formada a partir de insucessos econômicos, traços africanos e orientalizantes, advindos dos membros de sua família, e devido à sua juventude etária. Sua incapacidade de bem governar o Império não viria de sua loucura, mas de sua pouca experiência (CAZENAVE; AUGUET, 1995, p. 192-193). Tanto Herodiano quanto Dion Cássio, historiadores que vivenciaram o período severiano, embasaram este ideário e alegaram que a juventude e a consequente imaturidade dos príncipes concorreram para o insucesso do curto governo colegiado de Geta e Caracala, no qual apenas conseguiram efetivar juntos os funerais do pai, Septímio Severo, antes do assassinato de Geta a mando do irmão.

Herodiano (Hist., III, 10, 3-4) nos conta que, desde a mais tenra idade, os dois irmãos não se entendiam:

Mas os dois filhos, que eram já dois rapazes, foram corrompidos em seus costumes pela luxuosa vida de Roma e pelo excessivo afã de espetáculos, de corridas de bigas e de festas. Além disso, os dois irmãos não se entendiam. Começaram a brigar por causa de rivalidades infantis, devido a lutas travadas entre codornas, pelejas de galos e combates entre crianças. [...] Em nada tinham os mesmos gostos, pois o que era agradável a um era odioso ao outro. Seus aduladores e servos aumentavam ainda mais a sua inimizade [...]. Severo ao dar-se conta do fato tentava reconciliá-los e corrigi-los.

Severo, assim, sabia desta inimizade desde a mais precoce infância e procurou resolvê-la para criar um governo colegiado para seus sucessores, como foi o de Marco Aurélio e de Lúcio Vero. Severo mostrava o tesouro repleto de riquezas e os templos cheios de moedas, para demonstrar que para manter a abundância conseguida só restava imperar a concórdia entre os herdeiros:

Severo queria, na realidade, apartar seus filhos da vida de Roma e que gozassem de uma vida honesta, já que os via constantemente se entregarem aos espetáculos, mais do que convinha aos Imperadores. Sua conhecida rivalidade nestes espetáculos, ao provocarem enfrentamentos e desacordos constantes, turvou seus sentimentos fraternais e os incitou a uma profunda inimizade. Antonino (Caracala) estava especialmente insuportável desde que havia se desembaraçado de Plautiano, mas respeitava e temia seu pai. Maquinava por todos os meios a morte da filha de Plautiano, sua própria esposa. Mas Severo a exilou na Sicília em companhia de seu irmão [...]. Severo tentava continuamente reconciliar seus filhos e induzi-los à concórdia e à união, recordando-os mitos e dramas antigos nos quais sempre a desgraça sobrevinha como consequência de disputas entre irmãos. [...] Aproveitava todas as ocasiões para fazê-los refletir, rogando algumas vezes e repreendendo em outras, e se esforçava para reconciliá-los por meio 
de conselhos, mas eles não o escutavam. Ao contrário, se rebelavam e iam de mal a pior. Ao serem jovens e transbordantes de saúde, por meio de seu poder imperial, sentiam uma insaciável inclinação a todo tipo de prazeres, com cada um de seus aduladores os incitando em sentido contrário, tanto para prestar serviços a seus desejos e vergonhosas paixões, quanto em busca de novidades com as quais agradar ao que adulavam e desgostar ao seu irmão. Severo não deixou de castigar aos que surpreendeu efetivando estes atos (Hdn., Hist., III, 13, 4).

Esta discórdia continuou quando cresceram e foram galgando vários cargos públicos da hierarquia romana:

Não usavam os mesmos alojamentos, nem comiam juntos; cada um olhava com grande receio tudo o que comiam ou bebiam [...] por medo de que algum criado tivesse posto um veneno. [...] Dividiram o palácio e cada um habitou a sua parte. Todas as passagens privadas foram fechadas e somente permaneceram abertas as entradas públicas. Cada um nomeou seus próprios guardas, e nunca eram vistos juntos, a não ser em breves aparições em público (Hdn., Hist., IV, 1, 2-5).

Herodiano ressalta que a ida para a Bretanha teria sido uma estratégia de Severo para tentar aproximar os irmãos ao longo das batalhas. Para sobreviverem, eles teriam que perceber que convinha que lutassem juntos. As batalhas na Bretanha podiam trazer triunfos, títulos e glórias para todos os Augustos. Contudo, os dois irmãos permaneceram separados. Enquanto Geta cuidava da justiça e da administração do Império, Caracala era quem ia para as contendas, atento somente à sua pessoa (Hdn., Hist., III, 14, 2-5; III, 14, 9). Caracala apenas fingia amizade a Geta após a morte de Severo, esperando o melhor momento para se livrar do irmão e de seus assessores (Hdn., Hist., III, 15, 7).

Dion Cássio também afirma que Severo travou batalhas contra os bretões para afastar os dois filhos de Roma e para tentar acalmá-los e integrá-los (Cass. Dio, Hist. Rom., LXXVII, 11, 1). Dividiam o ódio por Plautiano (Cass. Dio, Hist. Rom., LXXVII, 2, 4), que assumia por vezes a postura de um pedagogo para os rapazes (Cass. Dio, Hist. Rom., LXXVII, 7, 1). Na visão diônea, Caracala causava alarme e ansiedade por sua vida sem temperança e pela sua evidente intenção de matar seu irmão e seu desejo de eliminar o próprio pai o mais rápido possível (Cass. Dio, Hist. Rom., LXXVII, 14, 1). Geta é costumeiramente descrito por Dion como o irmão mais novo de Caracala, que acabou perecendo por seu comando (Cass. Dio, Hist. Rom., LXXVIII, I, 3), mesmo sendo protegido dia e noite por uma guarda formada por soldados e atletas (Cass. Dio, Hist. Rom., LXXVIII, 2, 2). Assim, vemos como os dois autores acreditam que eram as facções políticas que existiam na capital que ajudavam a afastar e a gerar discórdia entre os irmãos, que acabaram não conseguindo repartir o poder imperial. 
Em 211, os dois irmãos participaram lado a lado da cerimônia de apoteose de Septímio, que os tornava filhos de um divus (Hdn., Hist., IV, 2, 1-11). Suas discordâncias eram tão grandes, que pensaram em dividir a administração do Império. Caracala ficaria com as províncias ocidentais e Geta com as orientais, fixando-se em Antioquia ou Alexandria. Contudo, foram impedidos de levarem este plano a cabo por Júlia Domna (Hdn., Hist., IV , 3, 5-7). O ódio e a rivalidade só aumentaram com o tempo e, principalmente, após a morte de Severo e a necessidade de dividir o governo:

Sempre que deviam efetuar nomeações para cargos militares ou civis, cada um queria promover seus próprios amigos. Quando administravam a justiça, emitiam juízos contrários [...]. Preparavam todo tipo de intrigas e tentavam persuadir copeiros e cozinheiros a pôr algum veneno mortal nas refeições. Mas isto não era uma tarefa fácil para ninguém, pois aumentavam as medidas de vigilância e de segurança (Hdn., Hist., IV, 4, 1-3).

Tanto que, logo após a divulgação da vontade severiana de organização de um governo colegiado, o Senado procedeu a sacrifícios em prol do estabelecimento da concórdia entre os jovens (Cass. Dio, Hist. Rom., LXXVIII, 1, 5). Dion Cássio enfatiza que ambos só tinham em comum os vícios por ultrajarem as mulheres e abusarem de meninos e por gastarem tempo com jogos e corridas de bigas, mas se haviam facções diversas, um sempre apoiava a contrária ao outro (Cass. Dio, Hist. Rom., LXXVII, 7, 1). Não foi à toa que Dion Cássio não estranhou o assassinato de Geta, pois, segundo ele, apesar de algumas tropas apoiarem o irmão mais novo, Caracala parecia governar sozinho após a morte do pai, em 211 (Cass. Dio, Hist. Rom., LXXVIII, 1, 1-3), sem que nenhuma concórdia pudesse ou parecesse uni-los. Em seu desprezo por Caracala, Dion afirma que ele procedia de três raças, devido às origens de seus pais e ao local de seu nascimento. Entretanto, delas, ele só teria desenvolvido os vícios: teria herdado a covardia dos gauleses, a crueldade dos africanos e a astúcia enganosa dos sírios (Cass. Dio, Hist. Rom., LXXVIII, 6, 1).

O desinteresse pela descrição da infância dos herdeiros permanece nos compêndios e biografias pagãs produzidos no século IV. Quase não temos notícias de seus períodos de formação, pois sua importância para a história política dos romanos só se iniciaria com sua elevação ao comando imperial. Eutrópio, em seu Breviário (VIII, 19, 3; 20, 1-2), apenas comenta o rápido governo colegiado, a morte de Geta e sua declaração como inimigo público, e a característica arisca e ameaçadora de Caracala, até sua morte em Osdroena, junto à cidade de Edessa. Aurélio Victor, no Livro dos Césares (20,32-34; 21, 1-6), segue o mesmo sistema lacunar e apenas reitera que os irmãos se detestavam tanto que "pareciam ter recebido ordens de se fazerem guerra um ao outro". Geta aparece 
descrito como possuindo um caráter mais moderado em ambos os resumos da história romana, o que acabava por irritar o irmão.

Na História Augusta (I, 2-5; II, 1-3), ao contrário, Caracala é apresentado em sua biografia como uma criança terna e engenhosa, amorosa com os pais, agradável com os amigos da família, estimado pelo povo e grato ao Senado. Enquanto viveu sob a tutela paterna, nunca se viu atrasado nos estudos, sempre preocupado em fazer o bem, em promover a liberalidade e a clemência:

Inclusive quando via os condenados serem lançados às feras, chorava ou escondia o olhar, motivo pelo qual a plebe o considerava adorável. Jovem de sete anos, deixou muito tempo de olhar o rosto do pai e o rosto do pai de um companheiro de jogos quando soube que este amigo havia sido duramente flagelado por ser judeu. Com sua interferência restituiu aos antioquenos e bizantinos seus antigos direitos, que haviam sido retirados por Severo, por eles terem ajudado a Nigro. [...] Tudo isso só ocorreu durante a sua mocidade. Uma vez superada esta fase, se tornou mais reservado, mais grave e até um tanto truculento de rosto, talvez pelos conselhos de seu pai ou por sua natural astúcia, ou porque se julgou chamado a emular Alexandre Magno da Macedônia. Tanto assim que muitos não acreditavam que se tratasse do mesmo garoto a quem haviam conhecido. [...] Era mais alto que seu pai e detestava seu irmão devido à sua grande modéstia.

Tal delicadeza e condescendência teriam se perdido com o passar do tempo. Já a biografia de Geta, na História Augusta (III, 2-4), traz ainda menos informações do que a dedicada ao irmão mais velho. Informa-se que, logo após seu nascimento, uma galinha da casa pôs um ovo purpúreo. Ao ser trazido à presença da família, Caracala o pegou e jogou ao solo. Júlia teria se assustado com a cena e declarado: "Maldito fratricida! Matastes teu irmão". Tal anedota serviu como presságio do futuro assassinato de Geta a mando do irmão. O biógrafo pinta um quadro pouco modesto de Geta, pois este teria modos ásperos quando criança, mas nunca se demonstrou desalmado ou desumano; entregue a aventuras eróticas na adolescência, foi guloso e amante dos vinhos. Teria sido constante nos estudos, recordava todas as sentenças legislativas de seu pai e era aborrecido sempre pelo irmão. Tratava a mãe com mais amor filial que o irmão e tinha uma voz musical. Ordenava a feitura de banquetes nos quais todos os pratos oferecidos deveriam começar com a mesma letra do alfabeto (SHA, Vida de Geta, III, 1-6; IV, 1-3; V, 1-2). Novamente, a partir destas informações preliminares, só temos acesso ao relato de seu assassinato.

As representações jovens, imberbes e de cabelos ainda um pouco alongados, dos dois herdeiros de Septímio, aparecem principalmente em moedas cunhadas durante o governo do pai (193 a 211), durante o qual se buscou divulgar uma imagem de concórdia no interior da família imperial e enfatizar a importância da estabilidade garantida pela passagem de poder do genitor para os filhos do gênero masculino. É 
nestes suportes numismáticos que temos acesso aos rostos imberbes dos príncipes severianos, apresentados como herdeiros capazes de manterem as alianças e os acordos feitos entre o patrono imperial e seus vários clientes, em meio civil e militar. As efígies dos adolescentes garantem a publicização da mensagem da renovação com continuidade, da manutenção das benesses e das prerrogativas existentes, capazes de garantir a harmonia e a abundância em solo imperial. O sangue gentílico ainda tinha o seu valor na condução das magistraturas, tanto que o imperador Marco Aurélio, de quem Septímio se tornou filho por adoção póstuma, fez questão que seu filho de sangue, Cômodo, o sucedesse no Principado (LINDSAY, 2009, p. 34).

O uso das imagens dos irmãos e herdeiros ampliou-se quando o Império passou a contar com três Augustos vivos, que deveriam demonstrar publicamente sua integração e coesão. Ricardo Cappelli (1963, p. 96-97) conseguiu fazer, em seu livro Profili imperiali romani, um quadro comparativo mostrando as transformações físicas de Geta e de Caracala, da infância à maturidade, usando somente os suportes numismáticos, começando com efígies dos retratados imberbes com cabelos cacheados e anelados até a utilização de imagens barbadas, destacadas pela ostentação de coroas de louros sobre a cabeça.

A título de exemplo, apresentamos a análise de algumas moedas. Optamos por exemplares de aureus e denarius (moedas de ouro e prata), que nos chegaram em melhor estado de conservação e de visualização, pois eram as moedas mais entesouradas pelo seu alto valor real. As moedas de ouro normalmente eram distribuídas como presentes nos congiários, enquanto as de prata eram usadas principalmente no comércio exterior. Como eram mais manuseadas no cotidiano, as moedas de menor valor, como os sestércios, nos chegaram bastante debilitadas, por isso optamos por formar séries de áureos e denários para este artigo.

Inicialmente, realçamos a preocupação em divulgar, por meio do suporte numismático, a harmonia que deveria existir entre os quatro membros da família severiana: o imperador Septímio, a esposa Júlia e os dois filhos jovens, mas já sendo preparados para ocupar funções públicas: 

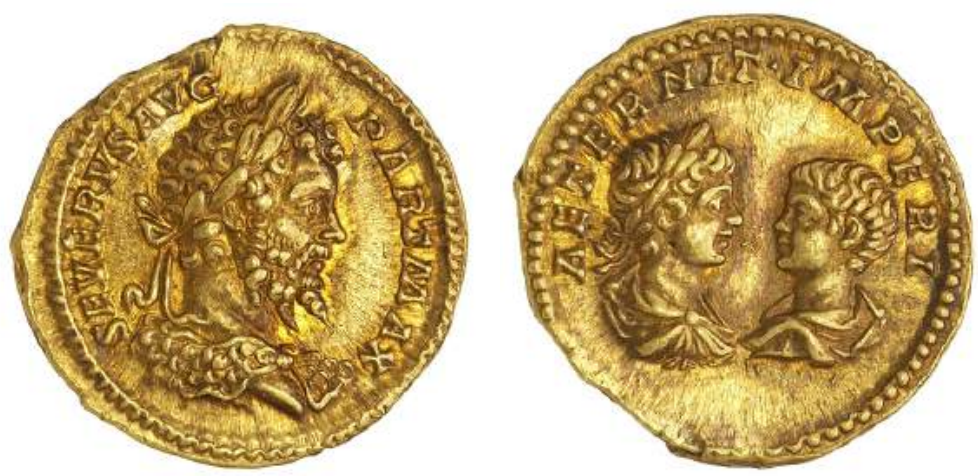

Anverso: legenda - SEVERVS AVG PART MAX - Busto de Severo laureado, portando uma pele de leão. Reverso: legenda - AETERNIT IMPERI - bustos de Caracala, laureado, e Geta. Referência: RIC IV Septimius Severus 155A (aureus). Origem e cronologia: Roma, 200-201.
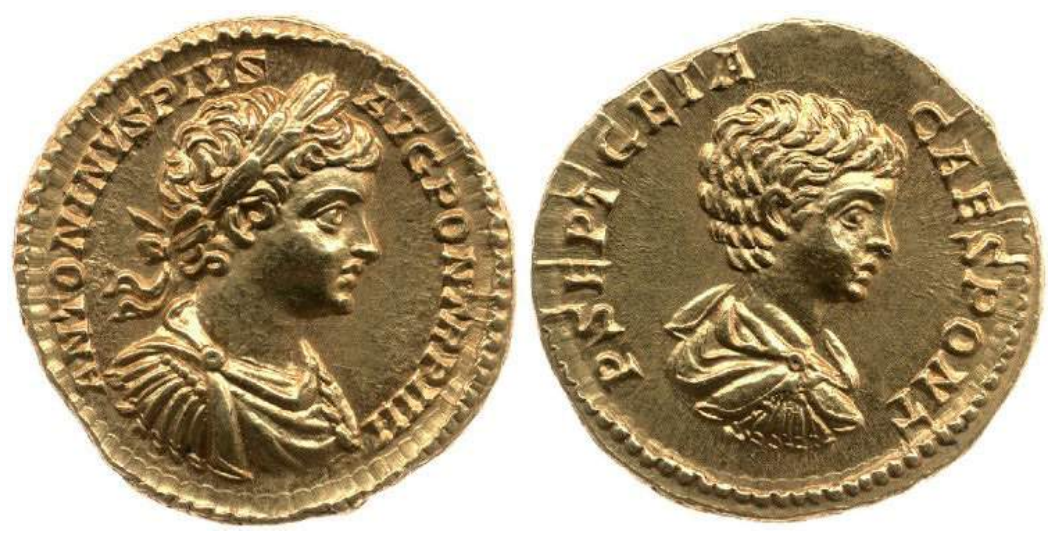

Anverso: legenda - ANTONINVS PIVS AVG PON TR P IIII - busto de Caracala laureado, portando uma toga drapeada. Reverso: legenda - P SEPT GETA CAES PONT - busto de Geta, portando toga drapeada. Referência: RIC IV Caracalla 53 (aureus). Origem e cronologia: Roma, 201.
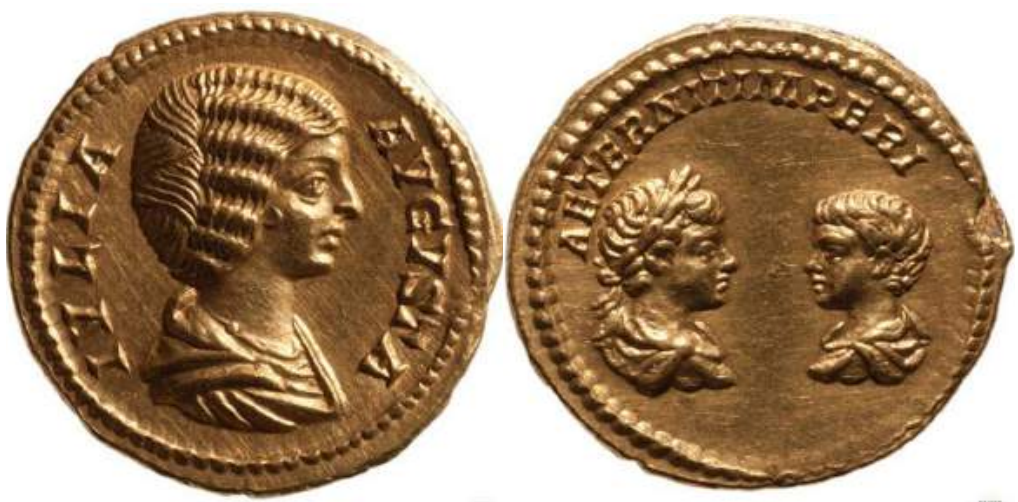

Anverso: legenda - IVLIA AVGVSTA - busto de Júlia Domna, com cabelo preso e toga drapeada. Reverso: legenda - AETERNIT IMPERI - bustos de Caracala laureado, com toga drapedeada, e de Geta, com toga drapeada. Referência: RÖ 37686 (aureus). Origem e cronologia: Roma, 196-211. 
Na primeira moeda, vemos, pela legenda do anverso, o interesse em divulgar as capacidades bélicas de Septímio, a partir das quais ele pôde ampliar o território controlado pelos romanos e que justifica a atribuição a ele do título de Particus Maximus, ou seja, o grande vencedor dos partos, mensagem realçada pelo fato de o busto ostentar uma coroa de louros e a pele de leão, relembrando as conquistas de Hércules. No reverso, a eternidade imperial, enfatizada na legenda, poderia ser mantida pela ascensão dos filhos, retratados bastante infantes nos bustos numismáticos. Na segunda moeda, podemos ver os bustos do Augusto Caracala, no anverso, e do César Geta, no reverso, cujas legendas explicitam os poderes e funções distribuídas aos príncipes: o pontificado e o poder tribunício, no caso de Caracala, pela quarta vez. Na terceira moeda, detectamos a integração da imagem materna de Júlia no anverso com os bustos dos filhos no reverso, cuja legenda novamente enfatiza a eternidade do Império, pela futura ascensão dos herdeiros ao comando imperial.

Nas duas moedas seguintes, ressaltamos a homenagem aos três Augustos, com os quais o Império poderia contar, permitindo que a estabilidade continuasse existindo no interior do território imperial. Na primeira, verificamos a coroa de louros no busto de Severo no anverso, no qual se destaca a legenda enfatizando a pietas do imperator, enquanto, no reverso, a coragem bélica dos três Augustos é enfatizada na legenda e na representação dos três personagens em postura militar, a cavalo, saudando o observador. Na segunda, associa-se a imagem de Geta, ainda César, retratado no anverso, à representação da Vitória alada posta de pé sobre uma biga em movimento, tendo o chicote que conduz os cavalos, em sua mão.
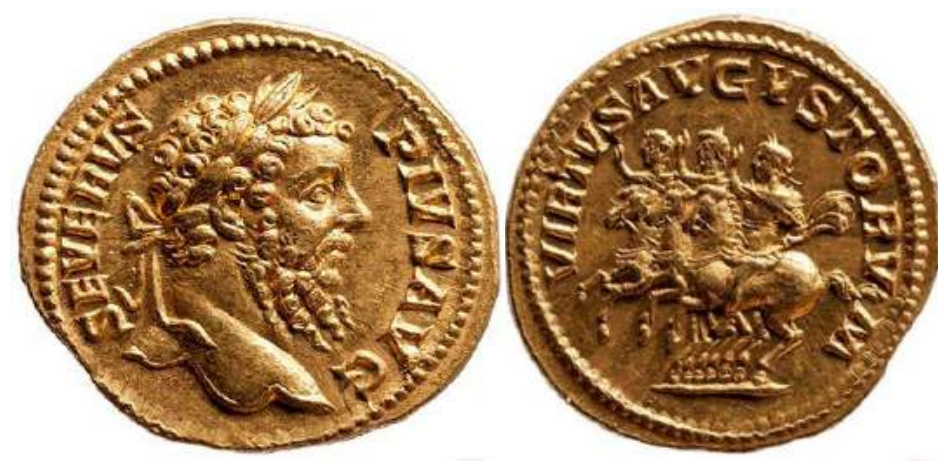

Anverso: legenda - SEVERVS PIVS AVG - busto de Septímio Severo laureado. Reverso: legenda - VIRTVS AVGVSTORVM - Septímio Severo, Caracala e Geta, em trajes e posturas militares, montados a cavalo, com mãos em posição de saudação. Referência: RÖ 36849 (aureus). Origem e cronologia: Roma, 202-211. 

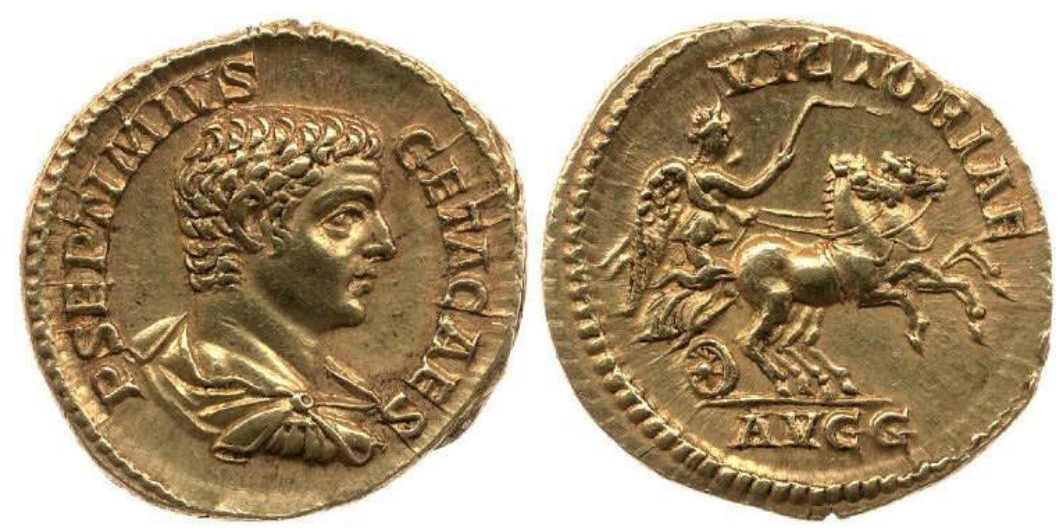

Anverso: legenda - P SEPTIMIVS GETA CAES - busto de Geta, portando toga drapeada. Reverso: legenda -VICTORIAE AVGG - representação de Vitória alada, com toga drapeada, de pé numa biga em movimento, com um chicote na mão direita. Referência: RIC IV Geta 55 (aureus). Origem e cronologia: Roma, 203-208.

Também é possível organizar uma série numismática com a comemoração da concessão do título de César ao jovem Geta. Nestas moedas, as legendas ora indicam o prenome de Geta como Públio, como nas fontes textuais, ora cunha-se Lúcio, como se para enfatizar sua ligação filial a Lúcio Septímio Severo, repetindo seu prenome:
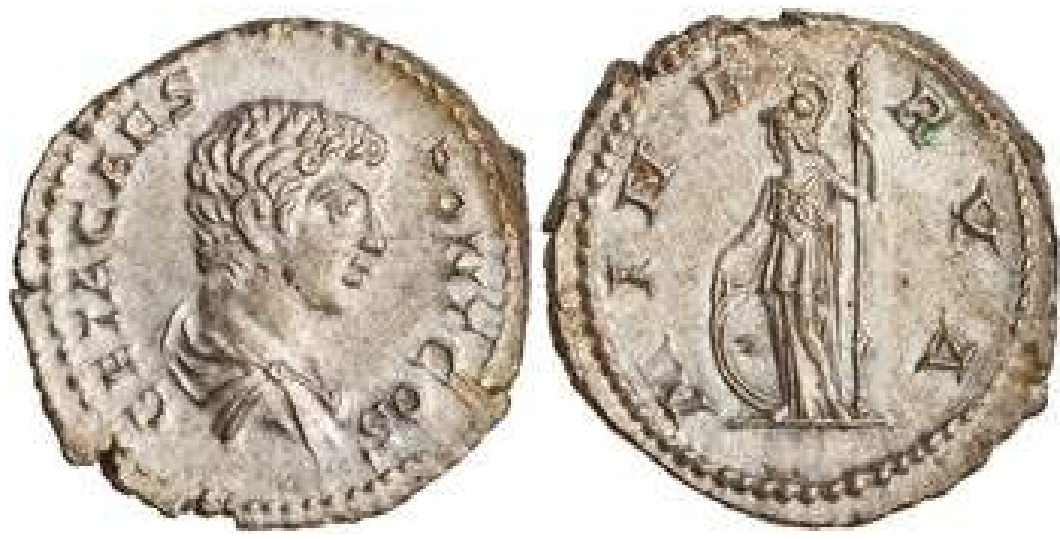

Anverso: legenda - GETA CAES PONT COS - busto de Geta, portando toga drapeada. Reverso: legenda MINERVA - representação da deusa Minerva com toga drapeada e elmo, de pé, portando escudo na mão esquerda e lança na mão direita. Referência: RIC IV Geta 30 (denarius). Origem e cronologia: Roma, 203-208. 


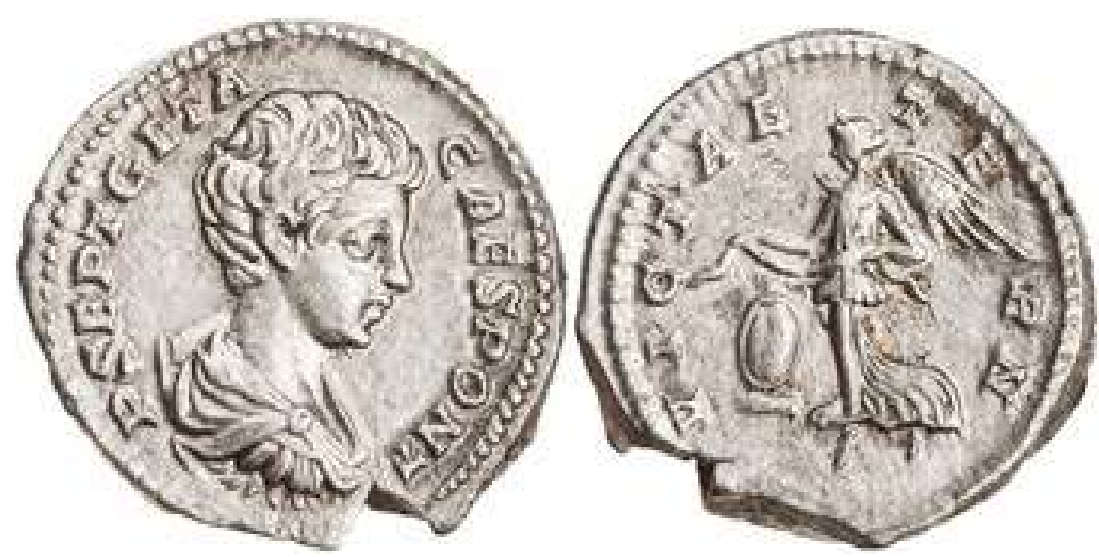

Anverso: legenda - P SEPT GETA CAES PONT - busto de Geta, portando toga drapeada. Reverso: legenda - VICT AETERN - representação de Vitória alada, com toga drapeada, segurando fitas em ambas as mãos, sobre um escudo disposto em sua própria base. Referência: RIC IV Geta 23 (denarius). Origem e cronologia: Roma, 200-202.
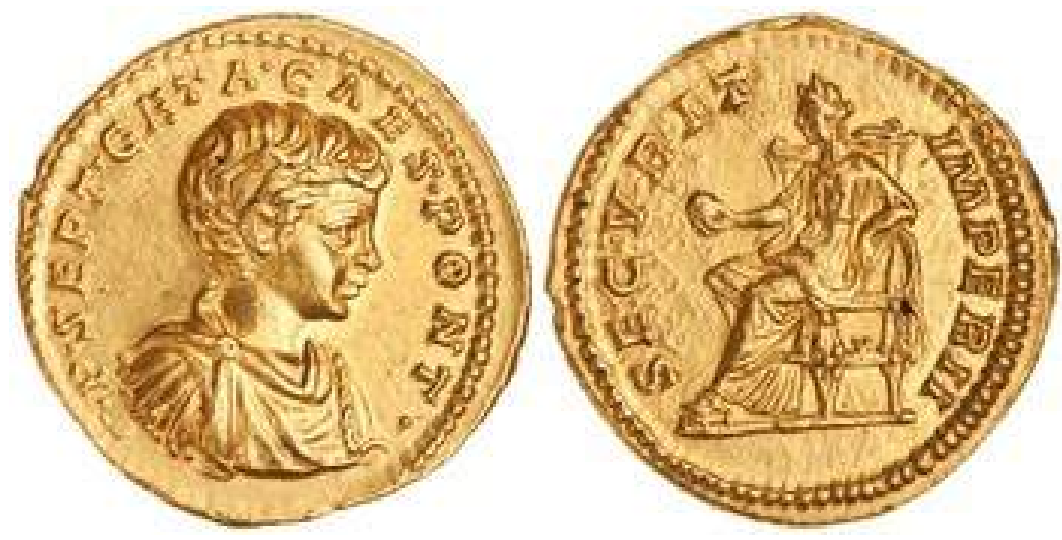

Anverso: legenda - P SEPT GETA CAES PONT - busto de Geta, portando toga drapeada. Reverso: legenda - SECVRIT IMPERII - representação de Securitas, sentada, com toga drapeada, segurando um globo na mão direita e um açoite para cavalos na mão esquerda. Referência: RIC IV Geta 20B (aureus). Origem e cronologia: Roma, 200-202.
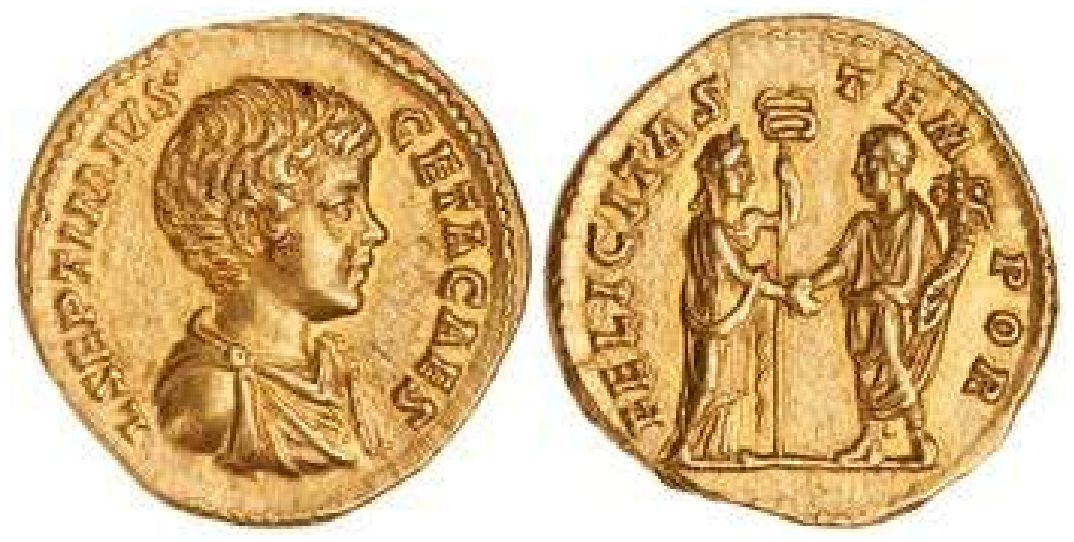

Anverso: legenda - L SEPTIMIVS GETA CAES - busto de Geta, portando toga drapeada.Reverso: legenda - FELICITAS TEMPOR - representação de Felicitas, de pé, com toga drapeada e diadema, segurando um caduceu na mão esquerda e apertando a mão de Geta, togado, de pé, segurando uma cornucópia na mão esquerda. Referência: RIC IV Geta 1 (aureus). Origem e cronologia: Roma, 198-200. 
Na primeira moeda desta série, notamos Geta comemorando seu pontificado e seu consulado, enquanto, no reverso, temos a representação da deusa Minerva, com seus atributos mais conhecidos, como o elmo, a lança e o escudo, lembrando que religião, aspectos militares e inteligência deveriam caminhar juntos. Na segunda, verificamos a imagem de Geta sendo vinculada à Vitória militar, representada com as fitas do sucesso bélico e sobre um escudo, quase um troféu. Na terceira, temos a associação da imagem do jovem César à representação da Segurança, portando um globo terrestre numa mão e um açoite, usado na condução das carruagens, na outra, ou seja, um votum de que a manutenção do domínio sobre todo o mundo conhecido na Antiguidade fosse mantido pela permanência do poder nas mãos da família severiana. Na quarta moeda, vemos o prenome Lúcio na legenda do anverso, que se une ao voto pela permanência de tempos felizes, pela representação de Geta, portando uma cornucópia, apertando a mão da Felicidade, que, por sua vez, sustenta um caduceu.

Destacamos ainda as moedas referentes à concessão de poderes e funções públicas ao jovem Caracala, antes mesmo de ele receber o título de Augusto. Desde muito cedo, divulgou-se seu poder tribunício, seu consulado e seu pontificado religioso, demonstrando que o herdeiro estava sendo formado para ser um bom governante em todos os níveis. Na primeira, notamos pela legenda do anverso que Caracala já havia recebido o numem antoninorum, passando a ser chamado de Marco Aurélio Antonino, e que havia recebido o título de César. E por este motivo, que o aproximava do futuro exercício da magistratura imperial, poder-se-ia divulgar, no reverso, a possibilidade de estabelecimento de uma Segurança Perpétua, como indicado na legenda, enquanto a imagem da deusa Minerva, devidamente trajada com suas insígnias, relembra que esta segurança adviria das atividades militares empreendidas pelos Severos, seja na formulação de estratégias competentes, seja na efetivação de batalhas vitoriosas.

Na segunda moeda desta série, atentamos para a ligação do César Caracala com a Esperança Perpétua, ressaltada na legenda do reverso, cuja imagem associa a Spes com a abundância, garantida pela coroa de flores e pela espiga de trigo. A estabilidade na sucessão garantiria, assim, a manutenção da produção de riquezas no território mantido pelos romanos. As duas últimas moedas foram cunhadas quando Caracala já tinha recebido o título de Augusto, como revelam as legendas dos anversos de ambas. No primeiro áureo, o reverso destaca, na legenda, o segundo poder tribunício do jovem Augusto, enquanto a imagem enfatiza seu sucesso militar, ao pô-lo em trajes bélicos, segurando uma vitória alada, com uma coroa de louros na mão, como que a oferecendo ao príncipe, disposta sobre um globo terrestre. Aos pés do triunfador, aparece, em tamanho reduzido, a representação de um cativo, derrotado, humilhado, vendo seu alforje vazio, 
com a identificação orientalizante garantida pelo uso do barrete frígio; portanto, divulgase a vitória sobre povos orientais, como os partos. No segundo áureo, pode-se perceber o regozijo com a concessão do quarto poder tribunício ao jovem Caracala, na legenda disposta no anverso, ao mesmo tempo que se identifica sua vinculação aos membros mais velhos da família severiana, no reverso, representados portando o homem uma coroa radiada, símbolo do poder de comando supremo, e a mulher, um diadema, estando ambos os bustos postos sobre uma lua crescente, que se liga diretamente à legenda que divulga a necessidade de uma Concórdia Eterna, capaz de estabelecer a continuidade da distribuiç̧ão de fartas benesses no interior do Império Romano, enquanto a família severiana estivesse no poder.
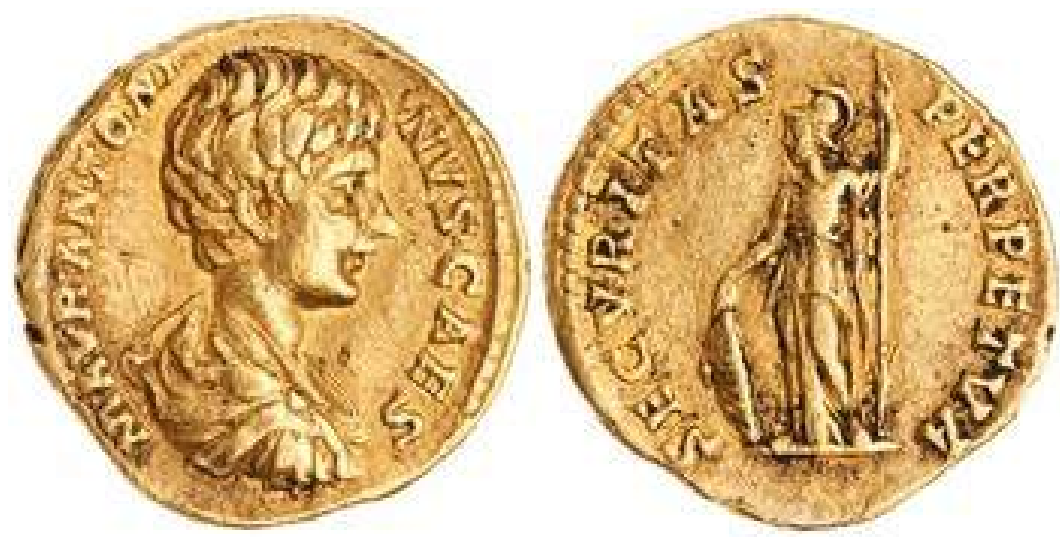

Anverso: legenda - M AVR ANTONINVS CAES - busto de Caracala, portando toga drapeada Reverso: legenda - SECVRITAS PERPETVA - representação da deusa Minerva, com elmo e toga drapeada, de pé, segurando lança na mão esquerda e bastão na mão direita. Referência: RIC IV Caracalla 2 (aureus). Origem e cronologia: Roma, 196.
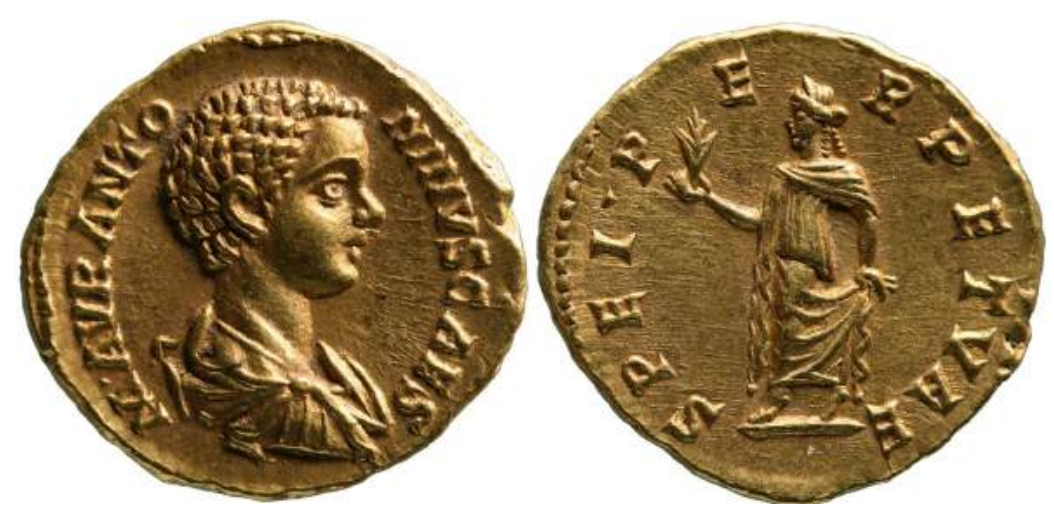

Anverso: legenda - M AVR ANTONINVS CAES - busto de Caracala, portando toga drapeada. Reverso: legenda - SPEI PERPETVAE - representação de Spes, de pé, com toga drapeada, em movimento para a esquerda, com coroa de flores na cabeça e espiga de trigo na mão direita. Referência: RIC IV Caracalla 5 (aureus). 

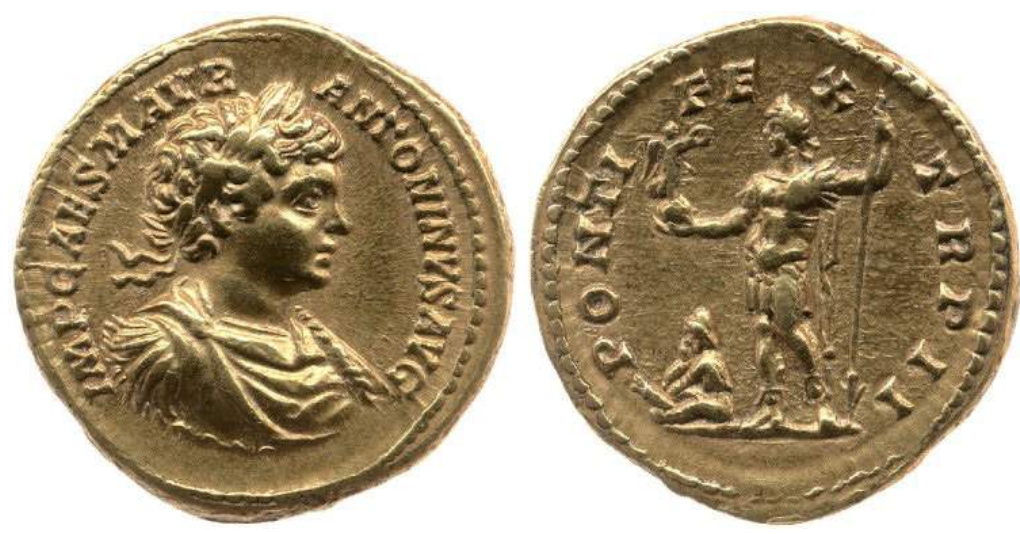

Anverso: legenda - IMP CAES M AVR ANTONINVS AVG - busto de Caracala, laureado e com toga drapeada. Reverso: legenda - PONTIFEX TR P II - Caracala, de pé, em trajes e postura militar, segurando uma Vitória alada, com a coroa de louros a mão, sobre um globo na mão direita e uma lança na mão esquerda. Aos seus pés, uma representação de um prisioneiro sentado, com o barrete frígio, segurando um alforje de flechas.

Referência: RIC IV Caracalla 27B (aureus). Origem e cronologia: Roma, 199.
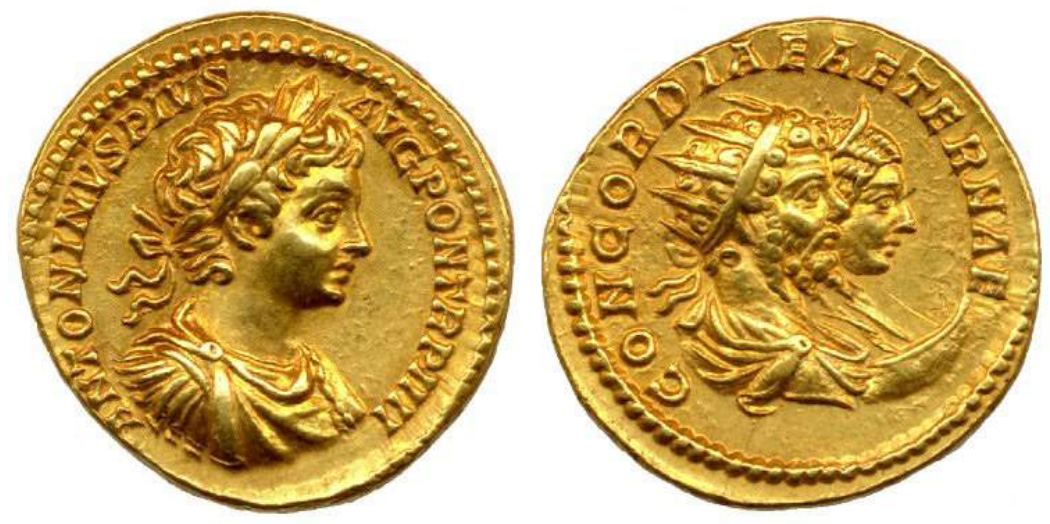

Anverso: legenda - ANTONINVS PIVS AVG PON TR P IIII - busto de Caracala, laureado e com toga drapeada. Reverso: legenda - CONCORDIAE AETERNAE - bustos de Septímio Severo, portando coroa radiada e toga drapeada, e de Júlia Domna, com diadema e toga drapeada, sobre uma lua crescente. Referência: RIC IV Caracalla 52 (aureus). Origem e cronologia: Roma, 201.

Por intermédio, portanto, de documentos de naturezas diversas, conseguimos refletir sobre a infância e a juventude de dois príncipes, Caracala e Geta, que assumiram o poder de forma colegiada após a morte do pai, mas que acabaram ambos sendo assassinados ainda jovens, sem deixarem herdeiros diretos. A formação destes jovens pouco importou aos historiadores e biógrafos, porém, com o auxílio da numismática, podemos ter um vislumbre dos rostos imberbes dos meninos, que chegaram ao poder de comando imperial acreditando serem eternos. 


\section{Referências}

\section{Documentação textual}

AAVV. Biógrafos e panegiristas latinos. Traducción de Luis Escolar Barreño et al. Madrid: Aguilar, 1969.

CASSIO DIONE. Storia Romana. Traduzione di Alessandro Stroppa. Milano: BUR, 1998.

CORNELIO NEPOTE. Vidas. Traducción de Manuel Segura Moreno. Madrid: Gredos, 1985.

DIO CASSIUS. Roman History. Translated by Earnest Cary. London: William Heinemann, 1961.

EPITOME DE CAESARIBUS. Traduit par M. N. A. Dubois. Paris: C.L.F. Panckoucke, 1846.

ERODIANO. Storia dell'Impero Romano dopo Marco Aurelio. Traduzione di Filippo Càssola. Firenze: Sansoni, 1967.

EUTROPE. Abrègé de l'Histoire Romaine. Traduit par Maurice Rat. Paris: Garnier, 1990.

EUTRÓPIO. Compêndio de História Romana. Tradução de Padre João Ravizza. Niterói: Escolas Professoras Salesianas, 1931.

EUTRÓPIO. Breviário. Traducción de Emma Falque. Madrid: Gredos, 1999.

HERODIANO. Historia del Imperio Romano después de Marco Aurélio. Traducción de Juan J. Torres Esbarranch. Madrid: Gredos, 1985.

HÉRODIEN. Histoire de l'Empire Romain après Marc-Aurèle. Traduit par Denis Roques. Paris: Les Belles Lettres, 1990.

SEXTUS AURELIUS VICTOR. Histoire des Césars. Traduit par Pierre Dufraigne. Paris: Les Belles Lettres, 1975.

HÉRODIEN. Libro de los Césares. Traducción de Emma Falque. Madrid: Gredos, 1999.

THE SCRIPTORES HISTORIAE AUGUSTAE. Translated by David Magie. London: William Heinemann, 1953.

\section{Documentação numismática}

MATTINGLY, H.; SYDENHAM, E. A. (ed.). The Roman imperial coinage. London: Spink and Son, 1936. v. 4.

MATTINGLY, H.; SYDENHAM, E. A. (ed.). Coins of the Roman Empire in the British Museum. London: British Museum, 1950. v. 5. 


\section{Obras de apoio}

ARIÈS, Ph. História social da infância e da família. Rio de Janeiro: Zahar, 1981.

BIRLEY, A. Septimius Severus: the African emperor. London: Routledge, 1999.

BRAVO, G.; GONZÁLEZ SALINERO, R. (eds.). Propaganda y persuasión en el mundo romano. Salamanca: Signifer, 2011.

CALDERINI, A. I Severi. Bologna: Licinio Cappelli, 1949.

CAPPELLI, R. Profili Imperiali Romani. Milano: Mursia, 1963.

CASINOS MORA, F. J. La noción romana de auctoritas y la responsabilidad por auctoritas. Granada: Comares, 2000.

CAZENAVE, M.; AUGUET, R. Os imperadores loucos. Sintra: Inquérito, 1995.

COULANGES, F. de. A cidade antiga. Rio de Janeiro: Zahar, 1982.

FRASCHETTI, A. O mundo romano. In: LEVI, G.; SCHMITT, J.-Cl. (org.). História dos jovens.

São Paulo: Companhia das Letras, 1996, p. 59-96. v. 1.

FRASCHETTI, A. Rome et le prince. Paris: Belin, 1994.

GONÇALVES, A. T. M. Lúcio Septímio Severo: a força de um norte-africano no Império

Romano. In: REDE, M. (org.). Vidas Antigas: ensaios biográficos da Antiguidade. São

Paulo: Intermeios, 2019, p. 159-190.

LENDON, J. E. Empire of honour. Oxford: University Press, 1997.

LINDSAY, H. Adoption in the Roman World. Cambridge: University Press, 2009.

MILLAR, F. The emperor in the Roman World. London: Duckworth, 1992.

MILLAR, F. A study of Cassius Dio. Oxford: Clarendon Press, 1964.

NODELMAN, S. Severan imperial portraiture. Yale University, unpublished.

SARTRE, M. Virilidades gregas. In: CORBIN, A.; COURTINE, J.; VIGARELLO, G. (dir.). História da virilidade. Petrópolis: Vozes, 2013, p.17-70. v. 1.

SCHNAPP, A. A imagem dos jovens na cidade grega. In: LEVI, G.; SCHMITT, J.-C. (org.).

História dos jovens. São Paulo: Companhia das Letras, 1996, p.19-58. v. 1.

SKINNER, M. B. Sexuality in Greek and Roman Culture. London: Blackwell, 2006.

TALBERT, R. J. A. The Senate of imperial Rome. Princeton: Princeton University Press, 1984.

THUILLIER, J.-P. Virilidades romanas: vir, virilitas, virtus. In: CORBIN, A.; COURTINE, J.;

VIGARELLO, G. (dir.). História da virilidade. Petrópolis: Vozes, 2013, p.71-124. v. 1.

VARNER, E. R. Mutilation and transformation: damnatio memoriae and Roman imperial portraiture. Boston: Brill, 2004.

VEYNE, P. O Império Romano. In: ARIÈS, Ph.; DUBY, G. (dir.). História da vida privada. São Paulo: Companhia das Letras, 1990, p.19-224. v. 1. 